\title{
Medetomidine- and Medetomidine-Ketamine-induced Immobilization in Blue Foxes (Alopex lagopus) and its Reversal by Atipamezole
}

\author{
By Harry H. Jalanka
}

Clinical Department, College of Veterinary Medicine, Helsinki, Finland.

\begin{abstract}
Jalanka, H.: Medetomidine- and medetomidine-ketamine-induced immobilization in bue foxes (Alopex lagopus) and its reversal by atipamezole. Acta vet. scand. 1990, 31, 63-71. - The sedative and immobilizing effects of the alpha $a_{2}$-adrenoceptor agonist medetomidine alone or combined with the dissociative anesthetic ketamine, were studied in blue foxes. Medetomidine at doses of 25 and $50 \mu \mathrm{g} / \mathrm{kg}$ induced moderate to deep sedation, but only with the highest medetomidine dose tested, $100 \mu \mathrm{g} / \mathrm{kg}$, was the immobilization complete. Medetomidine $50 \mu \mathrm{g} / \mathrm{kg}$ combined with ketamine $2.5 \mathrm{mg} / \mathrm{kg}$ rapidly induced complete immobilization, characterized by good myorelaxation, and no clinically significant alterations in serially determined hematologic and serum chemistry parameters.

The alpha $a_{2}$-adrenoceptor antagonist atipamezole effectively reversed the medetomidine- or medetomidine-ketamine-induced immobilizations. A transient increase in heart rates was noted after each atipamezole injection.
\end{abstract}

anesthesia; alpha ${ }_{2}$-adrenoceptor agonist, antagonist; hematology; serum chemistry.

\section{Introduction}

Complete and reliable immobilization is frequently needed to enable veterinary medical and research procedures in canid species other than the dog. The method for immobilization should be easy to use even under field conditions, have no significant adverse effects with clinical doses, and be reversible. The potent and selective alpha ${ }_{2}$-adrenoceptor agonist medetomidine' (4-[1-(2,3-dimethylphenyl)ethyl]-1H-imidazole hydrochloride) (Savola et al. 1986) has dose-dependent sedative, analgesic and muscle-relaxing properties in dogs (Vainio et al. 1987, Vainio \& Palmu 1989). When medetomidine is combined with the dissociative anesthetic ketami-

1. Medetomidine $1 \mathrm{mg} / \mathrm{ml}$ Farmos Group Ltd., P. O. Box 425, 20101 Turku, Finland.

2. Ketalar $50 \mathrm{mg} / \mathrm{ml}$ Parke-Davis \& Co., Pontypool, Gwent, United Kingdom. $\mathrm{ne}^{2}$, a more complete and reliable immobilization is achieved (Jalanka et al. 1989). Medetomidine-ketamine combinations have also been used in immobilization of a variety of nondomestic animal species (Jalanka 1987, 1988, 1989, Röken 1987).

Atipamezole $_{3}$ (MPV-1248; 4-[2-ethyl-2,3-dihydro-1H-inden-2-yl]-1H-imidazole hydrochloride) is a potent and selective alpha $a_{2}$ adrenoceptor antagonist (Virtanen et al. 1989, Virtanen \& MacDonald 1987). Atipamezole has been used in nondomestic animals to reverse the chemical immobilization induced by medetomidine, medetomidineketamine and xylazine (Jalanka 1987, 1988, 1989, Röken 1987).

The objectives of this study were to establish clinically useful doses for medetomidine or medetomidine-ketamine combinations in 
blue foxes (Alopex lagopus), to assess the induced immobilizations using clinical, hematologic, and serum chemistry parameters, and to determine the usefulness of atipamezole as a reversal agent.

\section{Materials and methods}

In November and December 1986 and in December 1987, medetomidine, alone or combined with ketamine, was administered to 43 blue foxes at the Research Farm of the Finnish Fur Breeders' Association, Veikkola, Finland. The blue foxes $[26$ males and $17 \mathrm{fe}$ males, mean $\pm \mathrm{SD}$ (range) values for age and weight were $1.7 \pm 1.5$ years $(0.5-5.5$ years) and $6.6 \pm 0.7 \mathrm{~kg}(3.8-9.0 \mathrm{~kg})$, respectively] that were managed in standard outdoor cages, were fasted overnight, but had free access to drinking water. All animals were brought indoors (ambient temperature 16$20^{\circ} \mathrm{C}$ ) in transfer cages and preweighed to enable accurate dose-planning. Medetomidine $(1 \mathrm{mg} / \mathrm{ml})$ and ketamine $(50 \mathrm{mg} / \mathrm{ml})$ were administered in separate syringes im into the triceps muscle. The administered doses, and the number of animals in each dose group, are presented in Fig. 1.

This study was divided into a phase of clinical orientation and into more detailed stu-

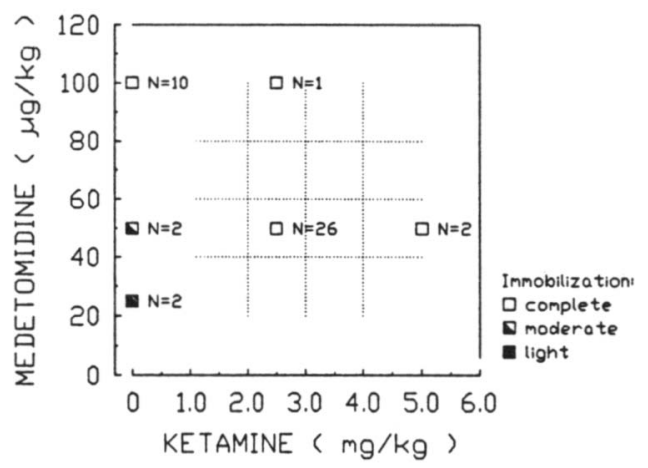

Figure 1. Medetomidine and ketamine doses (im) used and respective degree of immobilization in 43 blue foxes. dies. During each phase, the animals were monitored and the degree of immobilization was determined clinically by recording mucous membrane color, palpebral reflex, relaxation of the jaws and tongue, and by turning the animals. Possible adverse effects were recorded. During the immobilizations, no painful stimuli were used to determine the analgesic effects of the agents used.

During the initial trials, medetomidine was administered at doses of $25 \mu \mathrm{g} / \mathrm{kg}(\mathrm{n}=2), 50$ $\mu \mathrm{g} / \mathrm{kg}(\mathrm{n}=2)$ and $100 \mu \mathrm{g} / \mathrm{kg}(\mathrm{n}=2)$, and medetomidine + ketamine at doses of 50 $\mu \mathrm{g} / \mathrm{kg}+2.5 \mathrm{mg} / \mathrm{kg} \quad(\mathrm{n}=2), \quad \mu \mathrm{g} / \mathrm{kg}+5.0$ $\mathrm{mg} / \mathrm{kg}(\mathrm{n}=2)$ and $100 \mu \mathrm{g} / \mathrm{kg}+2.5 \mathrm{mg} / \mathrm{kg}$ $(n=1)$ to determine clinical dose-responses. Atipamezole $(5 \mathrm{mg} / \mathrm{ml})$ was administered at doses 5 times $(w / w)$ the initial medetomidine dose to 4 medetomidine-treated and to 3 medetomidine-ketamine-treated animals. Immobilizations and reversals were evaluated clinically. After these initial trials, medetomidine $100 \mu \mathrm{g} / \mathrm{kg}$ and a combination of medetomidine $50 \mu \mathrm{g} / \mathrm{kg}$ and ketamine 2.5 $\mathrm{mg} / \mathrm{kg}$ were chosen for more detailed studies.

Medetomidine $100 \mu \mathrm{g} / \mathrm{kg}$ was then administered to 7 blues foxes. The resulting immobilization was assessed clinically and by periodic ECG recordings (Cardiostat $1^{4}$ ) Atipamezole was administered either at 20 or 60 min after the initial medetomidine injection at doses and by routes indicated in Figs. 3 and 4. ECG's were recorded prior to the atipamezole injections, and continuously until the animals started to move and made recordings impossible. Time until arousal and type of recovery were recorded.

The combination of medetomidine $50 \mu \mathrm{g} / \mathrm{kg}$ and ketamine $2.5 \mathrm{mg} / \mathrm{kg}$ was administered by simultanous injections to 24 blue foxes.

\footnotetext{
3. Atipamezole $5 \mathrm{mg} / \mathrm{ml}$ Farmos Group Ltd., P. O. Box 425, 20101 Turku, Finland.

4. Cardiostat 1, Siemens-Elema AB, Sweden.
} 

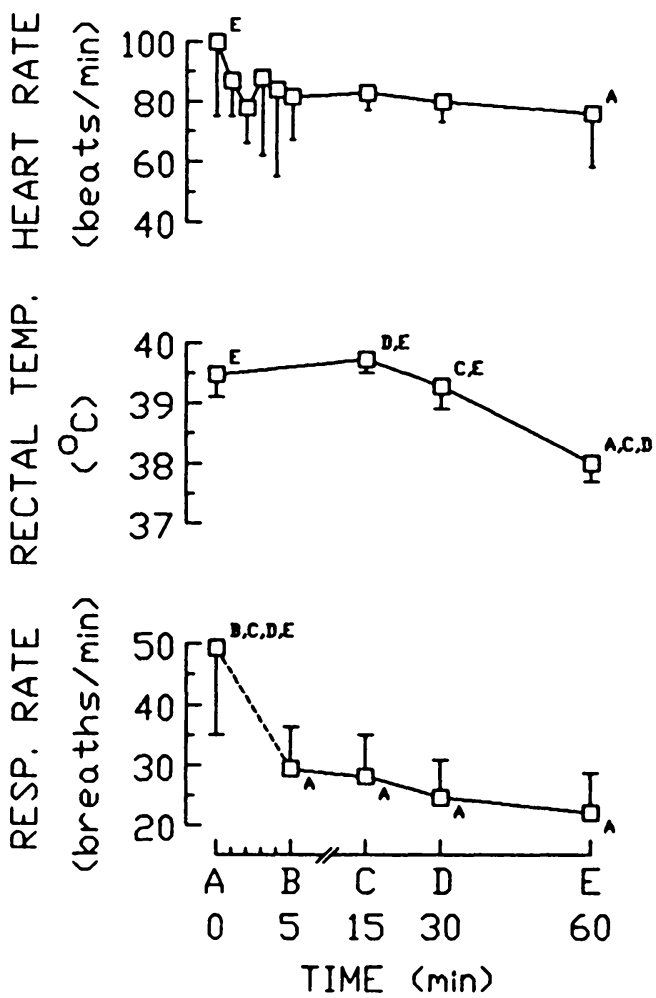

Figure 2. Mean and SD values for serially recorded heart rates, respiratory rates, and rectal temperatures in 6 blue foxes, immobilized with medetomidine $50 \mu \mathrm{g} / \mathrm{kg}$ and ketamine $2.5 \mathrm{mg} / \mathrm{kg}$ by simultaneous im injections. Baseline respiratory rates recorded before animals were physically restrained. A, B, C, D, $E=$ value statistically different $(P<0.05)$ from that in indicated column.
Serial determinations and recordings were performed in 6 of these animals (Fig. 2 and Table 2) and 18 animals were used for antagonist evaluation. The 6 blue foxes used for serial recordings were physically restrained prior to the anesthetic injections for baseline recordings, and were gradually released as the immobilization developed, usually within 3 to $4 \mathrm{~min}$. Heart rates were recorded by ECG monitoring prior to the anesthetic injections, continuously during the first 5 min, and at time points indicated in Fig. 2. Respiratory rates were determined before restraint (animals in cages) and as indicated in Fig. 2. Time points when rectal temperatures were recorded, and blood samples for hematology and serum chemistry were obtained, are presented in Fig. 2 and Table 2. Blood samples were stored at $1-3^{\circ} \mathrm{C}$ until hematology was completed or serum separated (less than $8 \mathrm{~h}$ ). Serum samples were stored at $20^{\circ} \mathrm{C}$ until analyzed. Methods and instrumentation were according to Scandinavian standards and have been reported previously (Jalanka 1988). No antagonists were used. The recovery was observed periodically for 3-4 h.

Atipamezole was administered to 18 blue foxes 15 min after treatments with medetomidine $50 \mu \mathrm{g} / \mathrm{kg}$ and ketamine $2.5 \mathrm{mg} / \mathrm{kg}$. Atipamezole was used at doses of $250 \mu \mathrm{g} / \mathrm{kg}$ im $(n=6), 125 \mathrm{ug} / \mathrm{kg} \mathrm{im}(\mathrm{n}=6)$ and 125 $\mathrm{ug} / \mathrm{kg}$ iv ( $\mathrm{n}=6$; one injection perivascularly,

Table 1. Data and characteristics on medetomidine and medetomidine-ketamineinduced immobilizations in blue foxes. Values expressed as mean $\pm \mathrm{SD}$ (range).

\begin{tabular}{lcc}
\hline & Medetomidine & Medetomidine + Ketamine \\
\hline$n$ & 7 & 24 \\
Dose(s) & $100 \mu \mathrm{g} / \mathrm{kg}$ & $50 \mu \mathrm{g} / \mathrm{kg}+2.5 \mathrm{mg} / \mathrm{kg}$ \\
Induction time (min) & $6.6 \pm 2.5$ & $2.5^{* * *} \pm 0.7$ \\
& $(3.5-10)$ & $(1.8-4.5)$ \\
Duration (min) & $\geq 60$ & $\leq 60$ \\
Total recovery time & not determined & $2-3$ hours \\
\hline
\end{tabular}

***Respective values significantly different $(P<0.001)$. 
Table 2. Results of serial determinations of hematological, and serum chemistry parameters in 6 blue foxes, immobilized with medetomidine $50 \mu \mathrm{g} / \mathrm{kg}$ and ketamine 2.5 $\mathrm{mg} / \mathrm{kg}$ by simultaneous im injections. Values expressed as mean $\pm \mathrm{SD}$ (range).

\begin{tabular}{|c|c|c|c|}
\hline & $\mathbf{A}$ & B & $\mathrm{C}$ \\
\hline Time (min after injection) & Before & 15 & 60 \\
\hline \multicolumn{4}{|l|}{ HEMATOLOGY } \\
\hline $\operatorname{PCV}(\%)$ & $\begin{array}{c}51.2^{b, c} \pm 4.4 \\
(45-58)\end{array}$ & $\begin{array}{c}45.8^{\mathrm{a}, c} \pm 4.4 \\
(40-51)\end{array}$ & $\begin{array}{c}42.7^{a, b} \pm 2.0 \\
(37-48)\end{array}$ \\
\hline Leukocytes (E9/liter) & $\begin{array}{c}6.8 \pm 1.5 \\
(5.8-8.5)\end{array}$ & $\begin{array}{c}6.1 \pm 1.3 \\
(4.7-7.2)\end{array}$ & $\begin{array}{c}5.9 \pm 0.6 \\
(5.2-6.4)\end{array}$ \\
\hline \multicolumn{4}{|l|}{ SERUM CHEMISTRY } \\
\hline ALT (U/liter) & $\begin{array}{c}55.8 \pm 28.1 \\
(26-104)\end{array}$ & $\begin{array}{c}54.5 \pm 23.7 \\
(29-94)\end{array}$ & $\begin{array}{c}57.3 \pm 25.7 \\
(34-104)\end{array}$ \\
\hline AST (U/liter) & $\begin{array}{c}25.5 \pm 3.6 \\
(21-32)\end{array}$ & $\begin{array}{c}30.8 \pm 6.2 \\
(24-42)\end{array}$ & $\begin{array}{c}32.5 \pm 6.8 \\
(<244)\end{array}$ \\
\hline Alkaline phosphatase (U/liter) & $\begin{array}{c}61.3 \pm 17.8 \\
(46-84)\end{array}$ & $\begin{array}{c}57.5 \pm 20.2 \\
(39-92)\end{array}$ & $\begin{array}{c}56.8 \pm 14.6 \\
(44-80)\end{array}$ \\
\hline Protein $\quad(\mathrm{g} /$ liter $)$ & $\begin{array}{c}71.6^{b} \pm 4.7 \\
(66.6-79.4)\end{array}$ & $\begin{array}{c}67.7^{a} \pm 4.5 \\
(63.9-75.8)\end{array}$ & $\begin{array}{c}68.5 \pm 5.7 \\
(61.9-75.5)\end{array}$ \\
\hline Glucose (mmol/liter) & $\begin{array}{c}8.4^{c} \pm 1.3 \\
(6.8-10.3)\end{array}$ & $\begin{array}{c}9.9 \pm 1.7 \\
(8.0-12.4)\end{array}$ & $\begin{array}{l}12.0^{\mathrm{a}} \pm 2.6 \\
(8.9-16.9)\end{array}$ \\
\hline Creatinine (mmol/liter) & $\begin{array}{c}60.3^{b} \pm 2.9 \\
(57-64)\end{array}$ & $\begin{array}{c}64.7^{\mathrm{a}} \pm 4.5 \\
(60-72)\end{array}$ & $\begin{array}{c}64.7 \pm 5.6 \\
(58-73)\end{array}$ \\
\hline (mmol/liter) & $\begin{array}{c}149.2^{c} \pm 2.9 \\
(145-153)\end{array}$ & $\begin{array}{l}151.0 \pm 4.9 \\
(144-158)\end{array}$ & $\begin{array}{c}146.7^{\mathrm{a}} \pm 3.3 \\
(142-150)\end{array}$ \\
\hline (mmol/liter) & $\begin{array}{c}4.9 \pm 0.3 \\
(4.5-5.2)\end{array}$ & $\begin{array}{c}4.8 \pm 0.3 \\
(4.5-5.2)\end{array}$ & $\begin{array}{c}5.2 \pm 0.8 \\
(4.5-6.8)\end{array}$ \\
\hline (mmol/liter) & $\begin{array}{c}114.0^{\circ} \pm 3.2 \\
(110-118)\end{array}$ & $\begin{array}{l}115.8 \pm 4.0 \\
(110-120)\end{array}$ & $\begin{array}{c}112.3^{\mathrm{a}} \pm 2.3 \\
(110-115)\end{array}$ \\
\hline (mmol/liter) & $\begin{array}{c}2.28 \pm 0.17 \\
(2.1-2.5)\end{array}$ & $\begin{array}{c}2.25 \pm 0.10 \\
(2.1-2.4)\end{array}$ & $\begin{array}{c}2.23 \pm 0.14 \\
(2.1-2.4)\end{array}$ \\
\hline P-inorg. (mmol/liter) & $\begin{array}{c}1.00^{b, c} \pm 0.23 \\
(0.72-1.31)\end{array}$ & $\begin{array}{l}1.72^{\mathrm{a}} \pm 0.44 \\
(0.92-2.07)\end{array}$ & $\begin{array}{l}1.79^{a} \pm 0.28 \\
(1.42-2.27)\end{array}$ \\
\hline
\end{tabular}

[ 3 males and 3 females; age and weights $1.7 \pm 0.4$ years $(1.5-2.5$ years) and $5.4 \pm 0.8 \mathrm{~kg}$ $(6.6-9.0 \mathrm{~kg})]$. a,b,c Value significantly different $(p<0.05)$ from that in columns $A, B$, and $C$.

results based on 5 recordings). ECG's were recorded prior to the atipamezole injection, and continuously for $5 \mathrm{~min}$ or until movements of the animals made recordings impossible. Time until arousal and type of recovery were recorded.

All statistical calculations and comparisons were performed using a computer program ${ }^{5}$ (Statgraphics $\left.{ }^{\circledR}\right)$. The Student's $t$-test for paired data was used to compare results of the serial recordings and determinations at different time points. The Student's $t$-test for unpaired data was used to compare induction and arousal times with different treatment.

\section{Results}

The clinical dose-response with the medetomidine and ketamine doses used is presented in Fig. 1. Medetomidine $25 \mu \mathrm{g} / \mathrm{kg}$ sedated 


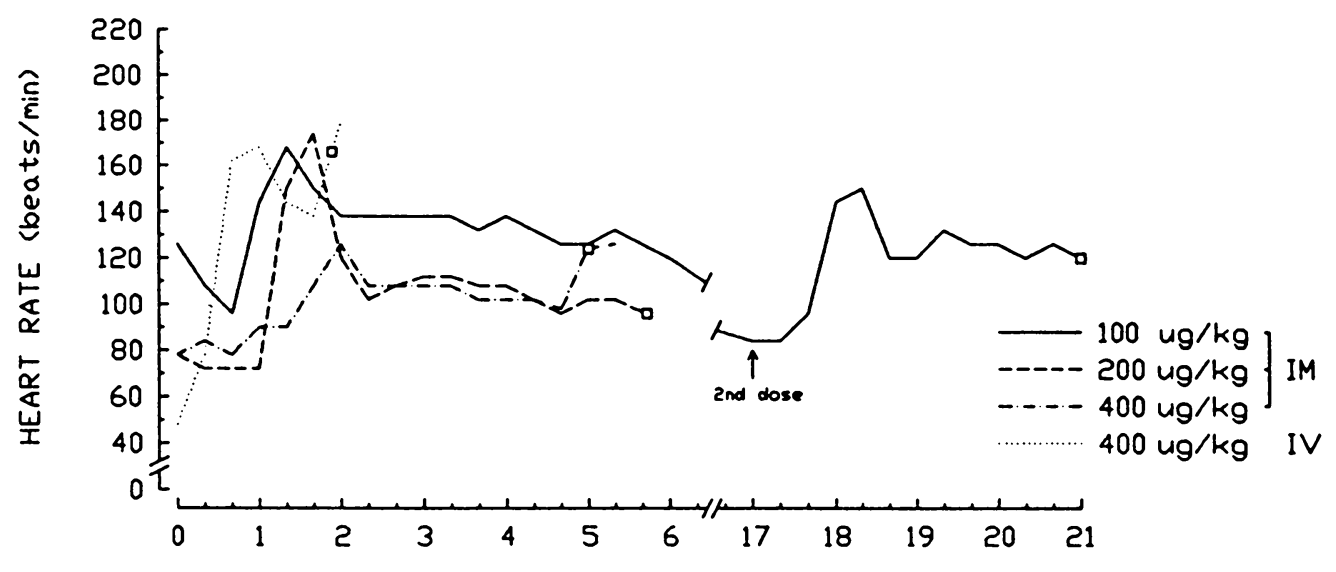

TIME AFTER ATIPAMEZOLE INJECTION (min)

Figure 3. Continuously recorded heart rates in 4 blue foxes, treated with atipamezole at doses and by routes indicated, $20 \mathrm{~min}$ after an initial im injection of medetomidine $100 \mu \mathrm{g} / \mathrm{kg} .2$ nd dose = additional dose of atipamezole $213 \mu \mathrm{g} / \mathrm{kg}$ im was administered. $\square=$ arousal time.

the animals but they were easily aroused by approach or manipulation and able to run, with only slightly impaired coordination. Medetomidine $50 \mu \mathrm{g} / \mathrm{kg}$ induced deep sedation. However, apparently unconscious animals were aroused if turned over, showing increased muscle tone or movements, but were unable to move in a directed manner. Medetomidine $100 \mu \mathrm{g} / \mathrm{kg}$ immobilized the blue foxes completely (Table 1). With this dose, myorelaxation was good, and the jaws and tongue were relaxed. Mucous membrane color was mildly cyanotic. During 3 of 7 immobilizations, second degree atrioventricular blocks were noted in the ECG recordings. Duration of immobilization was not determined as most animals received atipamezole. The immobilization was still complete in 1 animal 2 hours after the initial medetomidine injection, and in the 3 animals that received atipamezole at $60 \mathrm{~min}$ (Fig. 4).

Medetomidine $50 \mu \mathrm{g} / \mathrm{kg}$ and ketamine 2.5 $\mathrm{mg} / \mathrm{kg}$ induced complete and reliable immo-

\footnotetext{
5. Statgraphics ${ }^{\otimes}$, STSC, Inc., Rockville, Maryland 20852, USA.
}

bilization (Table 1). Results of the serial recordings and determinations in 6 blue foxes immobilized with this combination are presented, and statistically significant alterations indicated, in Fig. 2 and Table 2. During the immobilization, myorelaxation and mucous membrane color were good, jaws and tongue relaxed, and capillary refill times approximately to $1 \mathrm{sec}$. No second degree atrioventricular blocks were noted in the medetomidine-ketamine-treated animals. At the end of the $60 \mathrm{~min}$ monitoring period, 2 animals were still completely and 4 moderately immobilized. All recoveries were uneventful.

Atipamezole effectively reversed the medetomidine- or medetomidine-ketamine-induced immobilizations. Heart rates and arousal times in 7 blue foxes, treated with different doses of atipamezole at 20 or 60 min after the initial injection of medetomidine $100 \mu \mathrm{g} / \mathrm{kg}$, are presented in Figs. 3 and 4. On one occasion, when atipamezole (100 $\mu \mathrm{g} / \mathrm{kg} \mathrm{im}$ ) was administered $20 \mathrm{~min}$ after medetomidine, no reversal effect was noted for $17 \mathrm{~min}$. A second dose of atipamezole 


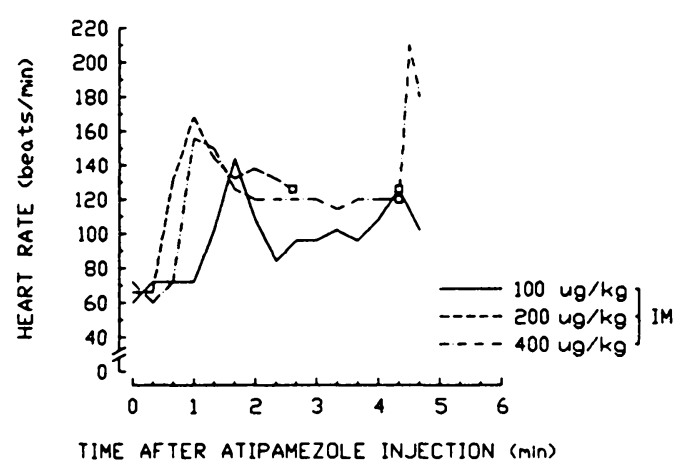

Figure 4. Continuously recorded heart rates in 3 blue foxes, treated with atipamezole im at doses indicated, $60 \mathrm{~min}$ after an initial im injection of medetomidine $100 \mathrm{ug} / \mathrm{kg} . \square=$ arousal time.

$213 \mu \mathrm{g} / \mathrm{kg}$ im reversed the immobilization in 4 min (Fig. 3). A comparison of the reversal effects of atipamezole at different doses and routes of administration in blue foxes, immobilized with medetomidine and ketamine, is presented in Table 3. Relative changes in the heart rates after atipamezole injections in these animals are presented in Fig. 5. An obvious, transient increase in heart rates of medetomidine- and medetomidine-ketamine-treated animals were noted within 1.5 min after each atipamezole injection, well before the animals showed any signs of arousal. The maximum individual heart rate recorded was 222 beats/min. The second degree atrioventricular blocks noted in some animals treated with medetomidine 100 $\mu \mathrm{g} / \mathrm{kg}$, disappeared as the heart rate increased.

Clinically, no adverse effects were noted with medetomidine or medetomidine-ketamine. No animals vomited. During the initial trials, 3 blue foxes experienced an excitatory period 6 to $8 \mathrm{~min}$ after atipamezole treatments. The animals first became nervous and overalert, then muscle fascicula-

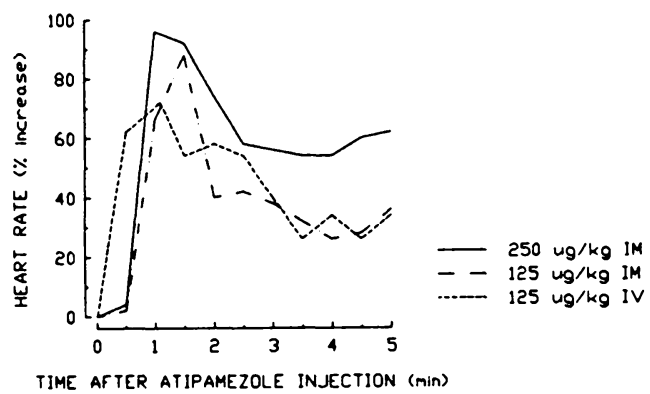

Figure 5. Mean values for relative changes in continuously recorded heart rates in blue foxes, treated with atipamezole at doses and by routes indicated, 15 min after initial im injection of medetomidine 50 $\mu \mathrm{g} / \mathrm{kg}$ and ketamine $2.5 \mathrm{mg} / \mathrm{kg}$. N $=6$ in $250 \mu \mathrm{g} / \mathrm{kg}$ im; $N=5$ in $125 \mu \mathrm{g} / \mathrm{kg}$ im; $\mathrm{N}=5$ in $125 \mu \mathrm{g} / \mathrm{kg}$, but reduced after $3 \mathrm{~min}$ as movements made recordings impossible.

Table 3. Data and characteristics on the use of atipamezole as a reversal agent in blue foxes.

Atipamezole was administered $15 \mathrm{~min}$ after initial im injections of medetomidine $50 \mu \mathrm{g} / \mathrm{kg}$ and ketamine $2.5 \mathrm{mg} / \mathrm{kg}$. Values expressed as mean \pm SD.

\begin{tabular}{lccc}
\hline & \multicolumn{3}{c}{ Dose and administrative route } \\
\cline { 2 - 4 } & $250 \mu \mathrm{g} / \mathrm{kg}$ im & $125 \mu \mathrm{g} / \mathrm{kg}$ im & $125 \mu \mathrm{g} / \mathrm{kg}$ iv \\
\hline$n$ & $\mathrm{~A}$ & $\mathrm{~B}$ & $\mathrm{C}$ \\
\hline Degree of immobilization at reversal & 6 & 6 & 5 \\
Atipamezole: medetomidine ratio $(\mathrm{w} / \mathrm{w})$ & complete & complete & complete \\
Arousal time (min) & $5: 1$ & $2.5: 1$ & $2.5: 1$ \\
& $4.1^{\mathrm{b}, \mathrm{c} \pm 0.9}$ & $6.4^{\mathrm{a}, \mathrm{c}} \pm 1.7$ & $2.4^{\mathrm{a}, \mathrm{b}} \pm 1.0$ \\
Type of recovery & $(3.6-6.0)$ & $(4.5-8.9)$ & $(1.5-4.0)$ \\
& most animals nervous & calm & calm \\
& and overalert & & \\
\hline
\end{tabular}

$a, b, c$ Value significantly different $(p<0.05)$ from that in columns $A, B$, and $C$. 
tions and extreme muscle tension developed for 30 to $40 \mathrm{sec}$, which gradually relaxed without treatment. One fox had been treated with medetomidine $100 \mu \mathrm{g} / \mathrm{kg}$ and given atipamezole $500 \mu \mathrm{g} / \mathrm{kg}$ iv $2 \mathrm{~h}$ later. One had been treated with medetomidine $50 \mu \mathrm{g} / \mathrm{kg}$ and ketamine $2.5 \mathrm{mg} / \mathrm{kg}$ and given atipamezole $250 \mu \mathrm{g} / \mathrm{kg}$ im $60 \mathrm{~min}$ later. One was treated with medetomidine $50 \mu \mathrm{g} / \mathrm{kg}$ and $\mathrm{ke}$ tamine $5 \mathrm{mg} / \mathrm{kg}$ and given atipamezole 250 $\mu \mathrm{g} / \mathrm{kg}$ im $50 \mathrm{~min}$ later. No similar effects were seen in later studies.

\section{Discussion}

In blue foxes, the response to different medetomidine doses resembled that in dogs with equivalent doses, although medetomidine $100 \mu \mathrm{g} / \mathrm{kg}$ is infrequently used in this species (Vainio et al. 1987). The 8 lower doses tested ( 25 and $50 \mu \mathrm{g} / \mathrm{kg}$ ) immobilized the animals incompletely and they were aroused by manipulations. Incompletely immobilized animals may be hazardous to handlers by being able to inflict trauma. Xylazine ${ }^{6}$ at doses of 2.7 to $3.9 \mathrm{mg} / \mathrm{kg}$ (together with atropine) has been used to sedate arctic wolves (Canis lupus) (Philo 1978). Gauze muzzles were applied to these wolves as they were able to bite extremely quickly if aroused by manipulations. In blue foxes, this is unlikely to happen if the highest tested dose $(100 \mu \mathrm{g} / \mathrm{kg})$ is used.

Medetomidine induces bradycardia, bradyarrhytmias, and an increase in the blood pressure, which is later followed by a decrease (Järvensivu et al. 1989). Bradycardia and sinus arrhytmia, related to changes in blood pressure, have been reported in xylazinetreated dogs (Hsu et al. 1985). Simultaneous decreases in heart rates and increases in mean arterial pressures were recorded in dogs after a combination of medetomidine $50 \mu \mathrm{g} / \mathrm{kg}$ and ketamine $2.5 \mathrm{mg} / \mathrm{kg}$ im (Jalan-

6. Rompun ${ }^{\oplus}$ Bayer, Leverkusen, West Germany. ka et al. 1989). The second degree atrioventricular blocks noted in blue foxes treated with medetomidine $100 \mu \mathrm{g} / \mathrm{kg}$ were probably similarly related to changes in blood pressure.

Medetomidine $50 \mu \mathrm{g} / \mathrm{kg}$ and ketamine 2.5 $\mathrm{mg} / \mathrm{kg}$ immobilized the blue foxes completely. If ketamine is used alone in nondomestic canids, doses of 20 to $35 \mathrm{mg} / \mathrm{kg}$ have been recommended, as have been doses of 10 $\mathrm{mg} / \mathrm{kg}$ when ketamine is combined with $\mathrm{xy}-$ lazine $2 \mathrm{mg} / \mathrm{kg}$ (Wallach \& Boever 1983). Much smaller ketamine doses (in medetomidine combinations) were used in this study, but they were equivalent to those reported to induce complete immobilization in snow leopards (Panthera uncia) (Jalanka 1989). Induction times in this study were only 2.5 $\pm 0.7 \mathrm{~min}$, indicating rapid distribution of the agents. The injections were administered into the triceps muscle as a standard. This was probably of significance as, in dogs, times to recumbency after xylazine-ketamine injections were markedly shorter when injections were given into the triceps muscle instead of the quadriceps muscle (McWade 1982).

No clinically significant alterations occurred in the serially recorded heart rates, respiratory rates, rectal temperatures, or in the hematologic or serum chemical parameters. The animals were physically restrained for baseline recordings. This probably caused some stress to the animals, increased the heart rates at the time and immediately after the anesthetic injections, and caused the slight elevation in the rectal temperatures noted in 15 min (Fig. 2).

Atipamezole effectively reversed the medetomidine or medetomidine-ketamine-induced immobilizations. Reversal was probably enhanced by the low ketamine doses used. The alpha $a_{2}$-adrenoceptor antagonist yohimbine has been reported to shorten the arousal 
times in ketamine-treated wolves but times until animals were able to walk in a directed manner were not different from controls (Kreeger \& Seal 1986). Even if arousal times could be recorded reliably, keeping of the blue foxes in small transfer cages did not permit to determine the time until the animals had fully recovered and e.g. would have been fit to be released in field conditions.

A transient increase in the heart rates was noted after each atipamezole injection, both in medetomidine- and medetomidine-ketamine-treated blue foxes. In horses, sedated with detomidine ${ }^{7}$, atipamezole induces a decrease in the blood pressure, which is compensated by an increase in the heart rate (Nilsfors \& Kvart 1986). In xylazine-ketamine-treated wolves, yohimbine decreases the mean arterial blood pressure and increases the heart rate to a maximum of 369 beats/ min within 3 min after iv doses of more than $0.2 \mathrm{mg} / \mathrm{kg}$ (Kreeger et al. 1987). After im atipamezole injections, the heart rates remained very stable in markhors (Capra falconeri megaceros) and increased only by $19 \%$ in snow leopards (Jalanka 1988, 1989). The much greater changes in heart rates noted in this study may suggest that atipamezole induces more pronounced alterations in blood pressure in blue foxes than it does in markhors or in snow leopards, or that there may be other species-related differences in regulatory mechanisms mediated via alpha ${ }^{-}$ adrenoceptors.

The excitatory periods noted in 3 blue foxes during the initial trials seemed to be related to the administration of atipamezole when the effects of medetomidine or medetomidine-ketamine were already wearing off. The doses per se were not exceptionally high. The reversals in blue foxes immobilized with

7. Domosedan Farmos Group Ltd., P. O. Box 425, 20101 Turku, Finland. medetomidine $50 \mu \mathrm{g} / \mathrm{kg}$ and ketamine 2.5 $\mathrm{mg} / \mathrm{kg}$ were calm after atipamezole 125 $\mu \mathrm{g} / \mathrm{kg}$ im, and after $125 \mu \mathrm{g} / \mathrm{kg}$ iv, but most animals became nervous and overalert when the dose of $250 \mu \mathrm{g} / \mathrm{kg}$ im was used (Table 3). In blue foxes, immobilized with medetomidine $100 \mu \mathrm{g} / \mathrm{kg}$, only the highest atipamezole dose, $400 \mu \mathrm{g} / \mathrm{kg}$, especially when administered iv, induced some overalertness after reversal. These findings suggest that the atipamezole dose should be adjusted according to the medetomidine dose used, and according to the time interval between anesthetic and antagonist injections.

\section{Acknowledgements}

This work was supported by grants from the Finnish Veterinary Research Foundation and the Research and Science Foundation of Farmos. I wish to thank Mr. Pertti Muuronen and Ms. Mary-Ann VaneTempest for their technical assistance, and Jaakko Mäkelä, Manager of Research Department, Finnish Fur Breeders' Association, for letting us use the facilities of the Veikkola Research Farm. Medetomidine and atipamezole were generously provided by Tapani Vähä-Vahe, DVM, Research Center, Farmos Group Ltd.

\section{References}

Hsu WH, Zheng-Xing Lu, Hembrough FB: Effect of xylazine on heart rate and arterial blood pressure in conscious dogs, as influenced by atropine, 4aminopyridine, doxapram, and yohimbine. J. Am. vet. med. Assoc. 1985, 186, 153-156.

Jalanka H: Clinical-pharmacological properties of a new sedative - medetomidine - and its antagonist, MPV-1248. In Proc. 1st Int. Conf. zool. and Avian Med. Hawaii 1987. Omnipress, Madison, Wisc. p. 530-534.

Jalanka $H$ : Evaluation of medetomidine- and ketamine-induced immobilization in markhors ( $\mathrm{Ca}$ pra falconeri megaceros) and its reversal by atipamezole. J. Zoo. Anim. Med. 1988, 19, (3): 95105.

Jalanka $H$ : Medetomidine- and ketamine-induced immobilization in snow leopards (Panthera uncia): doses, evaluation, and reversal by atipamezole. J. Zoo. and Wildl. Med. 1989, 20, 154-162. 
Jalanka H, Skutnabb K, Damstén Y: Preliminary results on the use of medetomidine-ketamine combinations in the dog. Acta vet. scand. 1989, Supplement 85 , p. $125-128$.

Järvensivu $P$, Kettunen $R$, Leskinen $M$, Pesola $M$, Rämö $P$, Timisjärvi J, Hirvonen L: The immediate circulatory effects of intravenously administered MPV-785 (medetomidine) in the dog. J. cardiovasc. Pharmacol. 1990, in press.

Kreeger TJ, Faggella AM, Seal US, Mech LD, Callahan $M$, Hall $B$ : Cardiovascular and behavioral responses of gray wolves to ketamine-xylazine immobilization and antagonism by yohimbine. J. Wildl. Dis. 1987, 23, 463-470.

Kreeger TJ, Seal US: Failure of yohimbine hydrochloride to antagonize ketamine hydrochloride immobilization in gray wolves. J. Wildl. Dis. 1986, 22, 600-603.

McWade DH: An evaluation of ketamine and xylazine in combination as agents for the remote chemical immobilization of feral and stray dogs. In: Nielsen L, Haigh JC, Fowler ME (eds.): Chemical Immobilization of North American Wildlife. Wisconsin Humane Society, Inc. 1982. p. 175187.

Nilsfors L, Kvart C: Preliminary report on the cardiorespiratory effects of the antagonist to detomidine, MPV-1248. Acta vet. scand. 1986, Supplement 82, p. 121-129.

Philo LM: Evaluation of xylazine for chemical restraint of captive arctic wolves. J. Am. vet. med. Assoc. 1978, 173, 1163-1166.

Röken BO: Medetomidine in zoo animal anaesthesia. In Proc. 1st Int. Conf. Zool. and Avian Med. Hawaii 1987. Omnipress, Madison. Wisc. p. 535538.

Savola J-M, Ruskoaho H, Puurunen J, Salonen JS, Kärki NT: Evidence for medetomidine as a selec- tive and potent agonist at alpha $\mathrm{a}_{2}$-adrenoceptors. J. auton. Pharmacol. 1986, 5, 275-284.

Vainio $O$, Palmu L: Cardiovascular and respiratory effects of medetomidine in dogs and influence of anticholinergics. Acta vet. scand. 1989, 30, 401407.

Vainio O, Palmu L, Virtanen R, Wecksell J: Medetomidine, a new sedative and analgesic drug for dogs and cats. J. Assoc. vet. Anaesth. (U.K.) 1987, 14, 53-55.

Virtanen $R$, MacDonald $E$ : Reversal of the sedati$\mathrm{ve} /$ analgesic and other effects of detomidine and medetomidine by MPV-1248, a novel alpha ${ }_{2}$-antagonist. Pharmacol. \& Toxicol. 1987, 60, (Supplement III), 53.

Virtanen $R$, Savola $J-M$, Saano $V$ : Highly selective and specific antagonism of central and peripheral alpha ${ }_{2}$-adrenoceptors by atipamezole. Arch. int. Pharmacodyn. 1989, 297, 190-204.

Wallach JD, Boever WJ: Diseases of Exotic Animals. W. B. Saunders Co., Philadelphia 1983, p. 405-463.

\begin{abstract}
Sammandrag
Medetomidin-och medetomidin-ketamin inducerad immobilisation hos bldrav (Alopex lagopus) samt dess upphävande med atipamezol.

Medetomidin allena eller i kombination med ketamin användes för immobilisering av blårăv. Med en dos pả 20 och $50 \mu \mathrm{g} / \mathrm{kg}$ medetomidin, uppnåddes sedation. En fullständig immobilisation och god muskelrelaxering uppnáddes med en dos på $100 \mu \mathrm{g} / \mathrm{kg}$ medetomidin och med $50 \mu \mathrm{g} / \mathrm{kg}$ medetomidin $\mathrm{i}$ kombination med $2.5 \mathrm{mg} / \mathrm{kg}$ ketamin. Atipamezol upphävde effektivt sedationen framkallad av medetomidin och medetomidin-ketamin.
\end{abstract}

(Accepted April 3, 1989).

Reprints may be requested from: Harry Jalanka, Helsinki Zoo, SF-00570 Helsinki, Finland. 